\title{
Analyzing Community Initiatives in UK's Energy Transition through the Lens of Sustainable Entrepreneurship
}

\author{
Abhijeet Acharya ${ }^{1} \&$ Lisa A. Cave ${ }^{2}$ \\ ${ }^{1}$ College of Management and Technology, Walden University, Minnesota, USA \\ ${ }^{2}$ Faculty, College of Management and Technology, Walden University, Minnesota, USA \\ Correspondence: Abhijeet Acharya, College of Management and Technology, Walden University, Minnesota, \\ USA. E-mail: abhijeet.acharya @waldenu.edu
}

Received: October 17, 2019

Accepted: November 10, 2020

Online Published: November 11, 2020

doi:10.5539/eer.v10n2p13

URL: https://doi.org/10.5539/eer.v10n2p13

\begin{abstract}
The low-carbon energy transition framed as a social-technical system can enable researchers to gain insight into the complex interaction between niche actors and the dominant regime under the current energy policy landscape. This paper aims to analyze community-led energy initiatives through the lens of sustainable entrepreneurship and discern business practices that these niche actors use in the social-technical setting of the energy transition. Niche actors such as Community Energy Cooperatives (CECs) develop bottom-up solutions and overcome social-cognitive norms through citizen engagement. Especially in the UK, such community initiatives face resistance from the dominant regime due to the unfavorable policies and centralized institutional arrangements. The business practices based on sustainable entrepreneurship can enable community groups to create social, economic, and environmental values for the local communities. In our analysis, we observed that CECs exhibit traits of a sustainable entrepreneur in their efforts to support energy transition. We discerned following business practices based on sustainable entrepreneurship that CECs employ in the UK: (1) mission-driven and locally focused, (2) commercial venturing and collaboration, and (3) grassroots innovations and shared knowledge. In this paper, we observed a strong connection between the CEC business practices and sustainable entrepreneurship that provides a foundation for future academic interests. Further, we noted that intermediary organizations, as part of the business ecosystem, play a crucial role in supporting the UK's community energy sector.
\end{abstract}

Keywords: sustainable entrepreneurship, community energy, energy transition, business ecosystem, grassroots innovations

\section{Introduction}

\subsection{Background}

Climate change policies aimed at reducing carbon emission necessitate low-carbon energy transition and changes in social norms and citizen behaviors to inculcate sustainable practices. A successful energy transition necessitates the diffusion of decentralized renewable energy systems and consumer-focused energy services (Caramizaru \& Uihlein, 2020). However, the existing energy market structure, societal norms, institutional arrangements, and technological lock-ins pose a social-technical challenge to energy companies (Geels et al., 2016). Large-centralized energy utilities characterized by technical lock-ins and investments in unsustainable practices lack the agility to create radical innovations and deploy low-carbon energy solutions to overcome these social-technical challenges (Hörisch, 2015). The market gap is an opportunity for community-led energy initiatives that establish decentralized low-carbon energy systems and promote sustainable practices to develop unique solutions (Gasbarro, Annunziata, Rizzi, \& Frey, 2017; Blazquez, Fuentes-Bracamontes, \& Manzano, 2019).

Community-led energy initiatives such as Community Energy Cooperatives (CECs) use entrepreneurial practices to facilitate the energy transition. CECs foster greater citizen engagement by creating grassroots innovation and involving them in local experimentation (Smith et al., 2016). Further, they create socio-economic and environmental benefits by generating low-carbon energy, retain communities' energy revenue within the local community, and avoid dependency on utility infrastructure (Becker, Kunze, \& Vancea, 2017; Huh, Yoon, \& 
Chung, 2019). Community-led energy initiatives can bring wider social and economic benefits, including generating income streams for the community, increasing community cohesion, and mutual trust within communities (DECC, 2015). Therefore, CECs are distinctively situated to address both the social and technical challenges of the energy transition. However, in their actions to create sustainable solutions and remain viable, community-led initiatives must overcome multiple challenges. The absence of favorable policy support and government subsidies, coupled with high entry barriers to energy markets, has limited the ability of CECs to engage in the energy transition (Smith et al., 2016). Further, the prevalence of centralized institutional arrangements restricts project support and funding for CECs (Huh et al., 2019). The unfavorable policies and dominant energy regime, especially in the UK, has resulted in the marginalization of some CECs (Smith et al., 2016). If CECs can overcome these challenges, they are uniquely positioned to create environmental value while delivering socio-economic benefits to local communities within the socio-technical setting of the energy transition.

Niche actors such as CECs demonstrate sustainable entrepreneurship (SE) traits when creating new social norms and practices, building new institutional arrangements, and exploring new markets in the energy transition (Gasbarro et al., 2017). Based on the triple-bottom-line approach, the SE concept asserts that sustainable development occurs when economic, social, and environmental values are concurrently delivered (Belz \& Binder, 2017; Sarango-Lalangui, Santos, \& Hormiga, 2018). The concept of SE hinges on creating new business opportunities in sustainable development with the ultimate motive to deliver economic, environmental, and social benefits to stakeholders (Belz \& Binder, 2017). The triple bottom line approach of the value creation process allows us to view CEC business practices through the lens of SE (Belz \& Binder, 2017; Sarango-Lalangui et al., 2018). In this paper, we aim to review CECs initiatives in the UK through the lens of SE and discern entrepreneurial business practices that CECs could apply to overcome the challenges they face in the UK's energy transition pathway.

\subsection{Aim of the Paper}

This paper aims to analyze community-led energy cooperative initiatives through the SE concept lens and discern business practices that they use in their actions to overcome challenges contributing to the energy transition. The SE concept enables us to identify innovative and entrepreneurial business practices of CECs who deliver social, economic, and environmental values to local communities as part of the energy transition. In section 1, we framed the energy transition as a social-technical system and discussed challenges faced by niche actors such as CECs in the energy transition pathways. In section 2 , we discuss the methodology used in this paper. In section 3 , we discuss the tenets of the SE concept applicable to CECs in the social-technical setting of the energy transition. The UK's community energy role, motives, and challenges in the energy transition and policy support for CECs are discussed in section 4. We analyze and discern business practices that CECs use and are important for generating social, economic, and environmental values to local communities in section 5. We conclude our paper in section 6 by highlighting the relevance of sustainable entrepreneurial practices in the community energy sector.

\section{Materials and Method}

In this paper, we develop theoretical concepts through logical arguments without intending to test them (Gilson \& Goldberg, 2015; Kahn \& Zeidler, 2017). We conduct a literature review on papers related to the SE concept published within the last five years. The substantive literature review helped us summarize the key tenets of the SE concept and develop a conceptual basis for analysis (Cropanzano, 2009). The review was confined to secondary sources of information from peer-reviewed papers, publications, and reports on the UK's community energy sector from public bodies and intermediary organizations. First, we discuss the evolution of the SE concept and its tenets in the social-technical setting that are imperative for niche organizations like CECs in energy transition pathways; and we highlight various innovative and entrepreneurial traits of sustainable entrepreneurs. Second, we discuss the UK's community energy sector, policy supports, issues, and problems using literature reviews. In the discussion section, we use the SE lens to analyze CECs initiatives using evidence from secondary sources. Based on the analysis, we discern entrepreneurial business practices that CECs could employ to overcome the challenges they face in the UK's energy transition pathways.

\section{Sustainable Entrepreneurship Concept}

The SE concept, emerged in the 1990s, focuses on the triple-bottom-line approach in sustainable development. SE is an entrepreneurship approach that aims at integrating three different values (economic, social, and environmental) to attain sustainable development (Belz \& Binder, 2017; Sarango-Lalangui et al., 2018). Scholars, including Elkington (1997), Anderson (1998), and Keogh and Polonsky (1998), contributed to the conceptualization of SE, which has drawn the research community's interest since the early 2000s. Sustainable entrepreneurs go beyond the enterprises' limits and make positive contributions to social and ecological systems 
(Belz \& Binder, 2017; Sarango-Lalangui et al., 2018). Schaltegger and Wagner (2011) empirically showed that small firms led by sustainable entrepreneurs are better placed to carry out radical sustainable innovation and partner with other organizations to enter the mass market. With their entrenched knowledge of the local community, environment, and economic matters, sustainable entrepreneurs quickly recognize and realize new business opportunities (Hanohov \& Baldacchino, 2018). Scholars have shown that similar to other entrepreneurship theories, SE enables organizations to (1) create business opportunities, (2) develop innovative solutions, and (3) collaborate with actors within the ecosystem (Belz \& Binder, 2017; Sarango-Lalangui et al., 2018; Schaltegger \& Wagner, 2011).

To understand how SE practices can help the energy transition in the social-technical setting, we review vital traits and drivers of SE practices. Such traits are important for niche organizations in their interactions with the dominant energy regimes. Interactions between niche actors and large energy companies result in re-configurations of social practices, technology re-alignments, and new institutional arrangements; therefore, providing a window of opportunity for new niche organizations to engage in SE practices (Geels et al., 2016; Gasbarro et al., 2017). Like any other entrepreneurial practice, recognizing new value creation opportunities and realizing them are essential to SE practices.

Belz and Binder (2017) highlighted key phases within the SE process are identifying new opportunities in social and environmental value creation and developing solutions to realize them. Hanohov and Baldacch (2018), through qualitative research, showed sustainable entrepreneurs are constantly cognizant of their surroundings, environmental, and social-economic developments, thereby are in a better position to recognize opportunities and respond quickly. Urbaniec's (2018) analyses show sustainable entrepreneurs use innovative solutions to realize new opportunities at the nexus of ecological and social issues. Using a quantitative research design, Vuorio, Puumalainen, and Fellnhofer (2018) showed opportunity recognition and risk-taking are interrelated concepts; sustainable entrepreneurs guided by intrinsic values are typically moderate risk-takers in their actions. In their review study, Kraus et al. (2018) showed that sustainable entrepreneurs take calculated risks to realize new business opportunities within the sustainability market since the return on investment in the sustainability-related market is typically slower compared to other markets. One strategy that sustainable entrepreneurs use to mitigate the market risks is to collaborate for new institutional arrangements to remain legitimate and competitive (Thompson, Herrmann, \& Hekkert, 2015).

Urbaniec (2018) stated innovativeness is one of the key traits of sustainable entrepreneurs; constant technological improvements and innovations are an integral part of SE practice. Gasbarro, Rizzi, and Frey (2018), through empirical research, showed sustainable entrepreneurs apply innovative solutions to overcome normative, cultural-cognitive, and regulative institutional barriers. Kraus et al. (2018) showed that the main idea behind SE conceptualization is the innovative approach and proactive behavior of entrepreneurs to be a forerunner.

Based on a bibliometric study, Sarango-Lalangui et al. (2018) showed the SE practices are locally embedded into communities and stated local embeddedness is another key trait in the SE. In the empirical research focused on the interplay between sustainable entrepreneurs and public authorities in sustainable energy transitions, Gasbarro et al. (2017) observed sustainable entrepreneurs focus on local businesses and strive to gain legitimacy and trust with local communities by being transparent in their actions. As part of the bottom-up initiative, sustainable entrepreneurs mobilize local communities for lobbying activities to create opinion multipliers and lobbying networks to overcome normative, institutional, and cultural-cognitive barriers (Gasbarro et al., 2018). Therefore, the key traits of SE are (1) change initiator, (2) recognize and realize new opportunities, (3) risk-taker, (4) innovative, and (5) locally embedded (Belz \& Binder, 2017; Sarango-Lalangui et al., 2018; Schaltegger \& Wagner, 2011). Altruistic values guide sustainable entrepreneurs in their actions to exhibit these traits (Vuorio et al., 2018). Having discussed the SE concept, key traits, and practices, we discuss how sustainable entrepreneurs can apply these traits in the social-technical setting.

The social-technical system of energy transition encourages the inclusion of social groups that play an active role in overcoming cognitive routines in energy usage and adopting sustainable practices. Therefore, a social-technical system ideal for studying niche actors' roles and their interaction with the existing energy regime (Geels \& Schot, 2007). The energy transition based on the social-technical system incorporates negotiations, consultations, and power struggles between social groups, the dominant regime, and policymakers. Social groups use these interactions to strengthen their strategies and apply resources to gain social acceptance and legitimacy of low-carbon technologies (Geels, Berkhout, \& van Vuuren, 2016). To study the interactions between niche actors and the energy regime requires a complete understanding of the social-technical system structure. The social-technical system involves interactions between actors at three different levels (1) community groups and social innovators at the micro-level, (2) the dominant regime at the meso-level, and (3) policymakers shaping 
energy trends at the macro-level (Geels et al., 2016). The micro-level actors represented by social innovators and niche organizations such as CECs, local authorities, and energy companies denote meso-level actors, and climate policymakers depict macro-level actors who influence the transition policy landscape (Gasbarro et al., 2017). In this study, we focus on micro-level actors and their interaction with the dominant regime at the meso-level.

Under the traditional demand and supply model, centralized energy companies treat energy as a tradable commodity without considering any of the energy-related value propositions. European countries want to create an energy landscape where consumers find benefit from decentralized and locally generated energy (Caramizaru \& Uihlein, 2020), and under the energy transition, they expect new value propositions from energy companies (Herbes et al., 2017). However, it is unlikely that the current market regime dominated by large incumbents with capital lock-ins in unsustainable practices can support new value propositions in energy services (Blazquez et al., 2019). The market changes driven by energy transition pathways, necessitate a shift from commodity-based energy trading to customer service-based business models (Blazquez et al., 2019). Arguably, energy companies can not offer such business model-driven services with centralized institutional arrangements; therefore, there is a need to re-configure and re-align institutions in the current energy regime. Niche actors can develop innovative bottom-up solutions, foster new institutional networks, and create new knowledge; therefore, supporting radical innovations and a sustainable transition (Gasbarro et al., 2017). CECs, in particular, integrate consumers into decentralized and distributed energy systems through social innovation; therefore, they can make a significant contribution to the energy transition (DECC, 2015; Caramizaru \& Uihlein, 2020).

Niche actors such as CECs can exploit windows of opportunity in a decentralized energy market and initiate radical transformations (Bolton \& Foxon, 2015). Smith et al. (2016) conceptualized energy cooperatives in the UK as a "strategic niche" who explore new opportunities amidst policy uncertainty, exploit resources, and continually adapt to external factors. Faced with up-scaling resistance posed by the regime's dominant structure, new entrants in collaboration with local authorities and city councils attempt to co-create new societal regimes and develop new forms of institutions (Gasbarro et al., 2017). In the UK's unfavorable policy regime, CECs strategically move away from isolated initiatives towards networking activities with intermediary organizations (Smith et al., 2016). Intermediaries are represented by public institutions, social organizations, or individual actors within the social-technical transition who nurture and empower CECs to work as local entrepreneurs (Bush et al., 2017). Intermediary organizations play a vital role in helping CECs achieve growth and scalability by disseminating practical knowledge and business advice at the grassroots level (Smith et al., 2016).

Researchers have used the SE concept to study how niche actors successfully create and realize new business opportunities in sustainability-related markets. Hörisch (2015) used the SE concept to analyze entrepreneurial traits of niche start-ups related to energy transition in Germany and observed niche actors create new business opportunities using transformative innovations at the nexus of social and ecological issues. In the social-technical setting, Gasbarro et al. (2017) analyzed 13 sustainable energy companies in Europe (Denmark, France, Germany, Italy, Switzerland, and the UK) and categorized four types of sustainable entrepreneur - hero, visionary, bandwagoner, and explorer based on their interactions with local authorities at the meso-level.

Building on our review of the SE framework in the social-technical setting of the energy transition, we observe key traits and business practices required for CECs to successfully diffuse decentralized energy systems and interact with the dominant energy regime. We noted sustainable entrepreneurs such as niche energy start-ups exploit new business opportunities to fill in energy market gaps using new business models and radical innovations. We also observed niche actors collaborate within the business ecosystem to create new institutional arrangements with the purpose to share their risks and remain viable. In the following section, we discuss CEC evolution, challenges faced by community groups, and the supporting role of intermediaries in the UK's community energy sector.

\section{Local Community Initiatives}

\subsection{CEC Evolution}

In European countries, local community-led energy initiatives have taken center-stage in the social-technical configuration of the energy transition as they provide decentralized and distributed energy systems. Such notable interest in CECs is due to social inclusiveness and grassroots activities in their offerings (Smith, 2016). Community energy projects are characterized by democratic governance and shared benefits through community engagement (Caramizaru \& Uihlein, 2020). CECs exist in various organizational forms in the UK, including cooperatives, social enterprises, volunteer organizations, and interest groups, who get involved in local experimentation to set up renewable energy systems (Smith et al., 2016). There are around 3500 energy communities across Europe, most of them located in Germany (1700), Denmark (700), Netherlands (500), and the UK (400) (Caramizaru \& Uihlein, 2020). Based on social entrepreneurial practices, CECs create social and 
environmental values; their actions support both profit and non-profit motives (Smith et al., 2016). CECs reduce information asymmetry related to energy pricing and consumption through community engagement and simultaneously re-invest profits in the community (Huybrechts \& Mertens, 2014; Hewitt et al., 2019). Conscious of energy justice and fuel poverty, CECs promote energy efficiency and energy-saving through consumer engagement (Herbes et al., 2017).

Traditional energy communities are based on a cooperative model governed by one member, one vote mechanism (Becker et al., 2017). However, in the last five years, the neo-collectivism approach for democratically governed and decentralized energy systems has seen the emergence of hybrid structures. The hybrid structures are practice-based cooperatives, where municipalities and local actors are given a prominent role in energy resource planning and regional development (Hewitt et al., 2019; Sait et al., 2019). Many community energy projects across Europe use these hybrid ownership structures involving community groups, private developers, and local authorities in the organization, development, and governance of CECs. In the UK, there are three main CEC organizational structures (1) Community Development Trusts (CDT), (2) Community Benefit Societies (CBS), and (3) Community Interest Companies (CIC). A board set up by community representatives manages hybrid structure in the UK, and the profits are re-invested back to the community (Hewitt et al., 2019). Community Energy England (2018) reported in 2017, around 47\% of CECs were based on CBS form in England, while 19\% of CECs had a traditional cooperative model, and the other 17\% were based on the CIC ownership.

\subsection{Challenges Faced by CECs}

Although community-led energy initiatives started in the 1990s, community energy growth remains asymmetric between European countries, mainly due to diverse energy policies and market configuration (Hewitt et al., 2019). Germany and Denmark support a coordinated energy market where niche actors and community groups are involved in the decision-making process. Conversely, the UK and the Netherlands aim to permeate entrepreneurship and innovation in community groups using market-driven competitive strategies (Creamer et al., 2018). Denmark and Germany have stable institutional supports and energy policies compared to the UK; the centralized nature of energy policies and competitive energy markets is the primary reason for the slow growth of the UK's community energy sector (Simcock, Willis \& Capener, 2016). Arguably, the UK aims to promote entrepreneurial and innovative practices in CECs using an open market strategy and reduced dependency on large energy incumbents (Eadson \& Foden, 2019). In England, the social enterprise models (CBS and CIC) are common ownership forms that do not rely on grant funding. In these forms, CECs show traits of entrepreneurship when they manage revenue stream from electricity generation and distribution to ensure (1) repayments of capital loans, (2) guaranteed payments to community shareholders, and (3) re-invest profits back into the communities (Simcock et al., 2016). We believe social enterprise models based on CBS and CIC are positive steps in developing community-led local energy initiatives in the UK. However, such social enterprise models without (1) an affordable source of project capital, (2) participation in the local energy market, and (3) supportive business ecosystems may not achieve their intended role in the energy transition.

Due to higher finance costs from banks and financial institutions, CECs struggle to secure project funding (Hall, Foxon \& Bolton, 2016). As renewable energy projects require large up-front capital costs, innovative low-interest financing models are necessary to overcome funding barriers (Caramizaru \& Uihlein, 2020). Additionally, the funding barrier has been compounded by the withdrawal of grant schemes and tax benefits to UK's community energy sector in 2015 (Curtin, McInerney, \& Johannsdottir, 2018). Instead of relying on grant schemes, CECs in the UK exhibit entrepreneurial practice and act resiliently, explore new business opportunities amidst an uncertain community energy policy landscape (Smith et al., 2016). The induction of the feed-in tariff (FIT) scheme in 2010 by UK authorities was a turning point and critical success factor in mobilizing citizens for community-led energy initiatives (Curtin et al., 2018). However, the UK's community energy growth fell after the reductions in FIT tariff rates in 2015; a further decline in growth is anticipated after full FIT withdrawal by 2019 (Hewitt et al., 2019). Reduction in FIT rates has adversely impacted the development of community-led energy initiatives in the UK (Eadson \& Foden, 2019). Community Energy England (2018) reported that as many as 66 community-led energy projects stalled in England, Northern Ireland, and Wales due to a reduction in FIT rates.

In the UK, policy asymmetries exist between the national and local governments. The central government favors centralized and large-scale energy generation; conversely, local authorities at city councils take a proactive role in setting up decentralized energy systems by involving community groups and intermediary organizations (Simcock et al., 2016). The UK has enacted market-driven schemes such as renewable obligations (RO) and Contract for Difference (CfD) to develop renewable energy systems. However, energy companies with larger 
generation capacity and higher risk appetite find these market-based policy instruments most favorable (Strachan et al., 2015). Conversely, such policy instruments remain counterproductive to CECs due to (1) the high upfront cost, (2) low generation by community-led initiatives, and (3) higher project risk (Curtin et al., 2018). Contrast to national government, the local authorities and city councils fill in top-down policy gaps through bottom-up initiatives to support energy transition. CECs play an active role in facilitating the decentralization of the energy system in a collaborative environment. Simultaneously, local authorities who are knowledgeable about local issues and available resources are in better position to support these initiatives (Caramizaru \& Uihlein, 2020).

Most CECs in the UK, run by committed volunteers driven by altruistic values, face a shortage of skilled professionals having a good understanding of energy policies and project development (Seyfang et al., 2014). Community groups struggle to recruit qualified professionals to run their businesses due to the small scale of operation. The present market-driven energy regime in the UK does not address the skill shortage, technical knowledge, and lack of social capital required in community-led local energy initiatives (Strachan et al., 2015). Therefore, CECs collaborate with intermediary organizations to fill in any professional gaps and seek their support as they are part of the business ecosystem (Seyfang et al., 2014). In the following section, we discuss intermediaries' role in nurturing and supporting community-led energy initiatives in the UK.

\subsection{Role of Intermediaries}

Intermediary organizations play multiple roles at the grassroots level, (1) networking to share knowledge and experiences, (2) supporting and providing project tool kits, (3) managing project funding options and programs, and (4) lobbying for policy support (Seyfang et al., 2014). Intermediaries act as umbrella organizations to support smaller community groups who become members; with permanent staff, these intermediaries offer development support, project management, funding, and administrative services at the regional level (Community Energy England, 2018). Intermediary organizations are represented by different actors, such as citizen groups, trusts, government bodies, or city councils at the local level (Seyfang et al., 2014). In the UK, civic bodies and councils primarily play the intermediary roles supporting community energy initiatives. Market-oriented and unfavorable UK policies have necessitated community-led energy initiatives to collaborate with intermediaries who are part of community energy business ecosystems (Acharya \& Cave, 2020). As part of strategic niche management, intermediary organizations being part of the business ecosystem, empower niche actors to add value in the energy transition process (Bush et al., 2017). In the absence of government grants and support funding in the UK, intermediary organizations help CECs explore and evaluate project funding opportunities (Seyfang et al., 2014).

In our analysis of CECs in the UK, we observed community groups must (1) develop partnerships with local authorities, (2) re-align existing institutions, and (3) create a bottom-up solution to overcome up-scaling challenges. As a sustainable entrepreneur, community groups should lobby with intermediaries to negotiate and win supports from local authorities and policymakers. Community-led energy initiatives focus on local value creation that results in mutual trust and credibility; such business practices are essential to overcome the social-cognitive barrier to increase the adoption of sustainability practices and renewable energy.

\section{Discussion}

In this review paper, we explore the entrepreneurial business practices that CECs employ to overcome the challenges faced in the UK's energy transition pathways. First, we discussed the SE concept and its tenets in the social-technical setting that are imperative for niche organizations like CECs in the energy transition. We then discussed the UK's community energy sector, the policy supports, issues, and problems faced by CECs. In this section, we use the SE concept as a lens to analyze CECs initiatives to discern business practices. We referred to secondary sources from public bodies and intermediary organizations in the UK and Europe. The three business practices that CECs use to overcome the challenges in the UK energy transition pathway are (1) mission-driven and locally focused, (2) commercial venturing and collaboration, and (3) grassroots innovations and shared knowledge. In our analysis, we observed, in challenging times, the community energy sector outlook remains positive; CECs explore new business opportunities to create local values through innovative and entrepreneurial business practices (Community Energy England, 2018; 2019).

\subsection{Mission-Driven and Locally Focused}

The energy transition objective in European countries is to achieve decarbonization targets and create social-economic benefits for local communities through decentralized and distributed energy systems. There is consensus among researchers about the purpose of community-led energy initiatives as these locally embedded initiatives bring social-economic benefits; therefore, added value for regional development (Smith et al., 2016). Like other European countries, the UK also witnessed a renewed interest in locally embedded entrepreneurial 
practices intending to empower local communities and provide energy justice. CECs keep the cost of energy within the local communities using community assets (wind turbines, solar panels), and surplus profits are re-invested in community benefit funds used to multiply community benefits (Caramizaru \& Uihlein, 2020).

Community Energy England (2018) reported creating positive social impacts in the local communities is the motivation for community energy projects. Additionally, $83 \mathrm{CECs}$, through their community benefit funds, re-invested a portion of their profit (a total of $£ 1.1$ millions) back to local communities to effect social changes by increasing the adoption of low carbon technologies and sustainable practices (Community Energy England, 2018). Community benefit funds are used to engender changes in energy consumption behaviors through energy efficiency upgrades in community buildings; using these initiatives, CECs create social cohesion and low-carbon awareness in the local communities (Community Energy England, 2019). According to Low Carbon Hub (2019), CECs envision that energy systems have a positive impact on the people and the planet; further, they aim to create new opportunities to change how people interact with energy and transform them from passive consumers into active and informed energy citizens. In Scotland, intending to add and retain values, local authorities support local energy economies based on innovative ideas and technologies. Such concepts could result in local energy generation matching with local demand, therefore, reducing dependency on electric grids and increasing consumption of locally owned renewables (Local Energy Scotland, 2016). Jones, Jenkinson, and Brammer (2019), in their report on low-carbon economic opportunities in England, highlighted Energy Local, a CIC organization using disruptive innovative solutions, created a local energy market by setting up Energy Local Clubs (ELC). These ELCs aim to match local energy demand with locally available renewable energy supplies, reducing dependency on high priced grid electricity. CECs get a fair price for green energy, local consumers get reduced electricity bills, and ultimately, the cost of energy remains within the community. Low Carbon Hub (2016) reported Oxfordshire spends around $£ 1.5$ billion annually on energy bills that go out of the local economy to large energy companies. Therefore, there is an opportunity to engage local communities and businesses in the low-carbon economy to retain sizable energy costs within the local community.

In our analysis, we observed CECs explore new opportunities to bring positive social changes in their local communities; they re-invest a portion of their profits to change societal norms related to citizen behaviors on energy use. We could establish a strong tie with the SE concept. Muñoz and Cohen (2018) suggested that sustainable entrepreneurs explore new opportunities and aspire to deliver positive social, environmental, and local economic outcomes. We also observed that CECs are locally embedded and strive to retain energy costs within the local community through innovative and entrepreneurial practices to create local values. The SE practice is embedded into the local community (Muñoz \& Cohen, 2018; Sarango-Lalangui et al., 2018), where sustainable entrepreneurs add values to local businesses, bring transparency to gain legitimacy among citizens (Gasbarro et al., 2017).

\subsection{Commercial Venturing and Collaboration}

Traditionally citizen-led initiatives in European countries have been based on the cooperative structure (Becker et al., 2017). However, due to (1) the high-interest rates of project funding, (2) entry barriers in the centralized energy market, and (3) withdrawal of FITs supports, CECs are required to collaborate with intermediaries within the business ecosystem to explore new opportunities (Acharya \& Cave, 2020). Community energy groups, faced with upscaling resistance from the dominant energy regime, collaborate with local authorities and councils to forge new institutional arrangements (Smith et al., 2016). Such institutional arrangements allow CECs to distribute risks and generate profits (Caramizaru \& Uihlein, 2020). New organizational forms, such as the shared ownership model, have emerged as a preferred institutional arrangement in several countries like Germany and the UK (Hewitt et al., 2019). In 2014, the UK government proposed hybrid structures (CIC and CBS) to promote entrepreneurial practices in CECs, providing community groups with opportunities to access large-scale commercial renewable energy projects. In the absence of FIT support and grants, such large-scale renewable energy projects can ensure long-term revenue visibility and profitability (Willis \& Simcock, 2019). It can be argued that hybrid ownership for CECs in the UK was part of a new market strategy to reduce the monopoly power of large energy companies (Eadson \& Foden, 2019).

In 2018, the UK government proposed five local energy hubs across England to engage local authorities in planning and developing decentralized energy systems; such a collaborative approach ensures alignment between local communities, local authorities, and private developers (Community Energy England, 2019). In 2015, Wiltshire Wildlife Community Energy (WWCE), a CBS, developed a financially sustainable 9.1 MW commercial-scale solar farm based on a shared ownership structure with a private developer without depending on any grant (Simcock et al., 2016). WWCE funded this project solely by selling community shares through a community share offer; investments ranged from $£ 500$ to $£ 100,000$ (Simcock et al., 2016). Burnham and Weston 
Energy CIC developed a 9.3MW commercial-scale solar farm through a bond offer to small investors. The project is one of the UK's largest community energy crowdfunding campaigns facilitated in collaboration with Triodos bank, which allowed small investors to participate in community energy projects (Burnham Weston Energy, 2020). In a new form of organization structure, CfR (Community for Renewable) CIC established over $£ 40$ million worth of anchor assets on behalf of 10 local communities in different parts of England (Community Energy England, 2018). In this split structure, local assets are owned by community groups, while CfR acts as an asset manager focusing on governance and energy generation (Community Energy England, 2018). Another form of organization structure in the UK is Energy4All that represents a network of organizations consisting of 27 CECs; this network supports new communities setting up their energy cooperatives, arranging project funding, and solving operational and financial issues of individual CECs (Caramizaru \& Uihlein, 2020).

In our analysis, we observed CECs get involved in entrepreneurial practices, set up new community projects without relying on government grants, and act as sustainable entrepreneurs who develop new assets to scale-up their operations and achieve profits (Kraus et al., 2018). CECs, as sustainable entrepreneurs, undertake moderate risk when they raise capital by partnering with social enterprise banks, private investors, and venture capitalists to create new assets; and diversify their risk to investors and other institutions (Sunny \& Shu; 2019). Further, we observed the inception of new organizational forms such as split-structures and networks of organizations. Sustainable entrepreneurs co-evolve new institutional arrangements to overcome the challenges they face to legitimize their business ventures (Gasbarro et al., 2017; Thompson et al., 2015). CECs in the UK as sustainable entrepreneurs re-orient and network themselves to overcome the challenges they face in upscaling, thereby initiate transformational changes in existing institutions or creating new institutional arrangements (Gasbarro et al. 2018).

\subsection{Grassroots Innovations and Shared Knowledge}

CECs create the opportunity for grassroots innovation by having an alternative vision and develop solutions that are either overlooked or considered non-profitable by conventional innovation systems (Smith, 2016). In their actions to create innovations, CECs collaborate with other business ecosystem actors (Hoppe \& De Vries, 2019). Like other European countries, the UK's community-led initiatives are anchored in grassroots innovation; such innovations occur in areas of technology, infrastructures, organizational forms, and markets to challenge current regimes (Smith et al., 2016). Community groups in the UK face difficulties securing financing from large financial institutions (Hall, Foxon, \& Bolton, 2016). To overcome this, CECs explore innovative financing models for commercial-scale funding. Additionally, community groups act as radical innovation niches to create the local energy market. When faced with high entry barriers from the centralized market, CECs develop disruptive innovation in collaboration with the network of actors and bring them into the market (Sait et al., 2019). Besides exploring innovative financing models or creating a market disruption, CECs also use collaborative innovation and shared knowledge to support bottom-up initiatives (Hoppe \& De Vries, 2019).

The UK's community energy sector remains optimistic, innovative, and resilient in the subsidy-free environment; 2017 witnessed higher innovative activities related to financing models, new technologies, and business models (Community Energy England, 2018). Innovation trends further increased in 2018 with 67 CECs and their intermediaries involved in innovation projects; these projects were at the grassroots level and related to local energy market models, demand-side responses, and non-traditional business models (Community Energy England, 2019). Energy Local CIC introduced a disruptive solution to bridge pricing discrepancies between the amount households pay and the local community renewable generators earn per unit of energy (Jones et al., 2019). The organization created a virtual local energy market that ensured local energy demand matched local renewable energy generation; only excess supply was imported from grids. This solution benefited both local consumers and the local generator (Jones et al., 2019). Energy Local's model is the energy market disruptor that encouraged local communities to generate and consume their own electricity. The replication of this grassroots innovation has the potential to reignite the community energy growth and enable communities to build new projects (Ashden, 2018). In similar lines, the Scottish government (2017) reported that community groups in Orkney have successfully developed innovative energy solutions without depending on the energy supply from the mainlands. This project was the UK's first smart grid project connecting renewable generation to Orkney's distribution network, which resulted in energy cost reduction and added values to communities (Scottish government, 2017).

Availability of low-interest financing is a concern in the UK's community energy sector; Community Energy England reported that in 2018, out of a total of 69 stalled projects, 15 projects stalled due to limited access to low-interest financing (Community Energy England, 2019). To overcome this challenge, CECs collaborate with intermediaries to explore low-interest finance models (Acharya \& Cave, 2020). CECs are exploring non-traditional financing routes such as project funding through shorter-term community bonds; these routes have 
helped improve community group's access to finance (Community Energy England, 2018). The CfR asset manager in the Burnham and Weston Energy cooperative collaborated with Triodos bank to utilize a crowdfunding platform, an innovative financial instrument. In this model, retail investors could invest directly in community energy projects and receive tax-free interests (Burnham Weston Energy, 2020).

Community energy in the UK relies on an innovative knowledge sharing system, quadruple helix. In quadruple helix, citizen groups drive the innovation process by utilizing social capital and resources and partners with three other groups academia, government, and business (Van Horne \& Dutot, 2017). Low Carbon Hub (2016), a social enterprise based in Oxfordshire, working on many innovative pilot projects to increase renewable energy diffusion. Low Carbon Hub collaborates with local city councils, universities in Oxford, and local enterprises to create shared knowledge for low carbon economic opportunities in Oxfordshire (Low Carbon Hub, 2016). In 2018, 33 CECs worked on energy storage pilot projects in partnership with commercial organizations and universities; and 29 CECs were actively involved in low carbon transport projects, including electric vehicles, car clubs, and charging infrastructure (Community Energy England, 2019). CECs exhibit SE traits, such as responsive to external changes, innovativeness, and local embeddedness. CEC's business practices are rooted in grassroots innovations and knowledge sharing.

In our analysis, we established a strong tie between the community-led energy initiatives with innovativeness in the SE concept. We observed CECs overcome challenges posed by the dominant energy regime by partnering with intermediaries who help them create grassroots innovations and shared knowledge. CECs act as sustainable entrepreneurs who develop innovative solutions as part of the sustainability transition (Urbaniec, 2018). In the energy transition process, CECs develop innovative solutions to up-scale their operations and explore new opportunities to work with public authorities and large market players, therefore, displaying traits of sustainable entrepreneurs (Gasbarro et al., 2017). The utilization of social capital and common resources to create shared knowledge for new opportunities in the UK's community energy sector depicts the entrepreneurial traits of CECs (Van Horne \& Dutot, 2017).

\section{Conclusion}

We used the SE concept to analyze various traits and business practices that CECs applied to deliver value to local communities. We discerned that CECs are (1) mission-driven and locally focused, (2) commercial venturing and collaborative, and (3) grassroots innovator who create innovative solutions and shared knowledge. In our analysis, we observed the outlook of CECs remains positive in the UK without depending on government funds and grants. The community groups are willing to explore new business opportunities to create social, environmental, and economic values using innovative and entrepreneurial business practices. In the absence of favorable government support for the UK's community energy sector, we also observed the crucial role of intermediary organizations in nurturing community-led initiatives. Intermediary organizations provide a space for grassroots innovations and support CECs in delivering social, environmental, and economic values to local communities.

We identified three business practices having notable links with the SE concept; this paper can provide a foundation for a future academic interest in community energy research. Since these business practices were developed using secondary data sources, we recommend empirical research to test them using a qualitative multi-case study. Our analyses also observed networked activities between community groups and local actors such as city councils and universities who collaborated to develop innovative solutions to overcome challenges in the energy transition. Recognizing the roles of local actors in regional energy planning through this paper, we request the UK's policymakers to accommodate these actors in the long-term community energy strategy.

\section{References}

Acharya, A., \& Cave, L. A. (2020). Feed-in-Tariff Removal in UK's Community Energy: Analysis and Recommendations for Business Practices. Journal of Sustainable Development, 13(4), 1-14. https://doi.org/10.5539/jsd.v13n4p1

Ashden. (2018). Energy Local wins prestigious Ashden Award for its tariff - supporting local renewable energy. Retrieved http://www.llangattockgreenvalleys.org/wp-content/uploads/06_18-Ashden-press-release-June-2018.pdf

Becker, S., Kunze, C., \& Vancea, M. (2017). Community energy and social entrepreneurship: Addressing purpose, organisation and embeddedness of renewable energy projects. Journal of Cleaner Production, 147(1), 25-36. https://doi.org/10.1016/j.jclepro.2017.01.048

Belz, F. M., \& Binder, J. K. (2017). Sustainable entrepreneurship: A convergent process model. Business 
Strategy and the Environment, 26(1), 1-17. https://doi.org/10.1002/bse.1887

Blazquez, J., Fuentes-Bracamontes, R., \& Manzano, B. (2019). A road map to navigate the energy transition. Energy Insight, 59, 1-18. Retrieved from https:/www.oxfordenergy.org/wpcms/wp-content/uploads/2019/10/A-road-map-to-navigate-the-energy-tran sition-Insight-59.pdf

Bolton, R., \& Foxon, T. J. (2015). Infrastructure transformation as a socio-technical process-Implications for the governance of energy distribution networks in the UK. Technological Forecasting and Social Change, 90, 538-550. https://doi.org/10.1016/j.techfore.2014.02.017

Burnham \& Weston Energy. (2020). Annual Report 2020. Retrieved from http://www.burnhamandwestonenergy.co.uk/wp-content/uploads/2018/01/Burnham-and-Weston-Energy-CI C-Annual-Report-March-2020.pdf

Bush, R. E., Bale, C. S., Powell, M., Gouldson, A., Taylor, P. G., \& Gale, W. F. (2017). The role of intermediaries in low carbon transitions-empowering innovations to unlock district heating in the UK. Journal of Cleaner Production, 148, 137-147. https://doi.org/10.1016/j.jclepro.2017.01.129

Caramizaru, A., \& Uihlein, A. (2020). Energy Communities: An Overview of Energy and Social Innovation. JRC Science for Policy Report JRC119433. https://doi.org/10.2760/180576

Community Energy England. (2018). Community energy state of the sector 2018 full report. Retrieved from https://communityenergyengland.org/pages/state-of-the-sector-report-2018/

Community Energy England. (2019). Community energy state of the sector 2019 full report. Retrieved from https://communityenergyengland.org/news/community-energy-state-of-the-sector-report-2019

Creamer, E., Eadson, W., van Veelen, B., Pinker, A., Tingey, M., Braunholtz-Speight, T., ... Lacey-Barnacle, M. (2018). Community energy: Entanglements of community, state, and private sector. Geography Compass, 12(7), 1-16. https://doi.org/10.1111/gec3.12378

Cropanzano, R. (2009). Writing nonempirical articles for journal of management: General thoughts and suggestions. Journal of Management, 35(6), 1304-1311. https://doi.org/10.1177/0149206309344118

Curtin, J., McInerney, C., \& Johannsdottir, L. (2018). How can financial incentives promote local ownership of onshore wind and solar projects? Case study evidence from Germany, Denmark, the UK and Ontario. Local Economy, 33(1), 40-62. https://doi.org/10.1177/0269094217751868

DECC. (2015). Community energy strategy update. Retrieved from https://www.gov.uk/government/

Eadson, W., \& Foden, M. (2019). State, community and the negotiated construction of energy markets: Community energy policy in England. Geoforum, 100, 21-31. https://doi.org/10.1016/j.geoforum.2019.02.006

Gasbarro, F., Annunziata, E., Rizzi, F., \& Frey, M. (2017). The interplay between sustainable entrepreneurs and public authorities: Evidence from sustainable energy transitions. Organization \& Environment, 30, $226-252$. https://doi.org/10.1177/1086026616669211

Gasbarro, F., Rizzi, F., \& Frey, M. (2018). Sustainable institutional entrepreneurship in practice: Insights from SMEs in the clean energy sector in Tuscany (Italy). International Journal of Entrepreneurial Behavior \& Research, 24, 476-498. https://doi.org/10.1108/IJEBR-11-2015-0259

Geels, F. W., \& Schot, J. (2007). Typology of sociotechnical transition pathways. Research Policy, 36(3), 399-417. https://doi.org/10.1016/j.respol.2007.01.003

Geels, F. W., Berkhout, F., \& van Vuuren, D. P. (2016). Bridging analytical approaches for low-carbon transitions. Nature Climate Change, 6(6), 576-583. https://doi.org/ 10.1038/nclimate2980

Geels, F. W., Kern, F., Fuchs, G., Hinderer, N., Kungl, G., Mylan, J., ... \& Wassermann, S. (2016). The enactment of socio-technical transition pathways: A reformulated typology and a comparative multi-level analysis of the German and UK low-carbon electricity transitions (1990-2014). Research Policy, 45, 896-913. https://doi.org/10.1016/j.respol.2016.01.015

Gilson, L. L., \& Goldberg, C. B. (2015). Editors' comment: So, what is a conceptual paper? Group \& Organization Management, 40(2), 127-130. https://doi.org/10.1177/1059601115576425

Hall, S., Foxon, T. J., \& Bolton, R. (2016). Financing the civic energy sector: How financial institutions affect ownership models in Germany and the United Kingdom. Energy Research \& Social Science, 12(2), 5-15. 
https://doi.org/10.1016/j.erss.2015.11.004

Hanohov, R., \& Baldacchino, L. (2018). Opportunity recognition in sustainable entrepreneurship: An exploratory study. International Journal of Entrepreneurial Behavior \& Research, 24, 333-358. https://doi.org/10.1108/IJEBR-12-2015-0275

Herbes, C., Brummer, V., Rognli, J., Blazejewski, S., \& Gericke, N. (2017). Responding to policy change: New business models for renewable energy cooperatives-Barriers perceived by cooperatives' members. Energy Policy, 109, 82-95. https://doi.org/10.1016/j.enpol.2017.06.051

Hewitt, R. J., Bradley, N., Baggio Compagnucci, A., Barlagne, C., Ceglarz, A., Cremades, R., ... \& Slee, B. (2019). Social innovation in community energy in Europe: A review of the evidence. Frontiers in Energy Research, 7(31), 1-27. https://doi.org/10.3389/fenrg.2019.00031

Hoppe, T., \& De Vries, G. (2019). Social innovation and the energy transition. Sustainability, 11(141), 1-13. https://doi.org/10.3390/su11010141

Hörisch, J. (2015). The role of sustainable entrepreneurship in sustainability transitions: A conceptual synthesis against the background of the multi-level perspective. Administrative Sciences, 5, 286-300. https://doi.org/10.3390/admsci5040286

Huh, T., Yoon, K. Y., \& Chung, I. R. (2019). Drivers and ideal types towards energy transition: Anticipating the futures scenarios of OECD countries. International Journal of Environmental Research and Public Health, 16(8), 1-16. https://doi.org/10.3390/ijerph16081441

Huybrechts, B., \& Mertens, S. (2014). The relevance of the cooperative model in the field of renewable energy. Annals of Public and Cooperative Economics, 85, 193-212. https://doi.org/10.1111/apce.12038

Jones, E., Jenkinson, C., \& Brammer, S. (2019). A toolkit for city regions and local authorities: Climate action co-benefits. Ashden. Retrieved from https://www.ashden.org/downloads/files/CAC-Chapters-all-FINAL.pdf

Kahn, S., \& Zeidler, D. L. (2017). A case for the use of conceptual analysis in science education research. Journal of Research in Science Teaching, 54(4), 538-551. https://doi.org/10.1002/tea.21376

Kraus, S., Burtscher, J., Vallaster, C., \& Angerer, M. (2018). Sustainable entrepreneurship orientation: A reflection on status-quo research on factors facilitating responsible managerial practices. Sustainability, 10(2), 1-21. https://doi.org/10.3390/su10020444

Local Energy Scotland. (2016). CARES progress and impact. Retrieved from https://www.localenergy.scot/media/96610/CARES-Progress-and-Impact.pdf

Low Carbon Hub. (2016). Community Energy Manifesto. Retrieved from https://www.lowcarbonhub.org/wp-content/uploads/2019/11/LCH_Manifesto_WEB.pdf

Low Carbon Hub. (2019). Social Impact report 2019. Retrieved from https://www.lowcarbonhub.org/wp-content/uploads/2019/11/LCH-IMPACT-REPORT-2019-LOWRES-1.pd $\mathrm{f}$

Muñoz, P., \& Cohen, B. (2018). Sustainable entrepreneurship research: Taking stock and looking ahead. Business Strategy and the Environment, 27(3), 300-322. https://doi.org/10.1002/bse.2000

Sait, M. A., Chigbu, U. E., Hamiduddin, I., \& De Vries, W. T. (2019). Renewable energy as an underutilised resource in cities: Germany's 'Energiewende' and lessons for post-brexit cities in the United Kingdom. Resources, 8(7), 1-27. https://doi.org/10.3390/resources8010007

Sarango-Lalangui, P., Santos, J. S., \& Hormiga, E. (2018). The development of sustainable entrepreneurship research field. Sustainability, 10(6), 1-19. https://doi.org/10.3390/su10062005

Schaltegger, S., \& Wagner, M. (2011). Sustainable entrepreneurship and sustainability innovation: Categories and interactions. Business Strategy and the Environment, 20, 222-237. https://doi.org/10.1002/bse.682

Scottish Government. (2017). Scottish energy strategy: The future of energy in Scotland. Retrieved from https://www.gov.scot/publications/scottish-energy-strategy-future-energy-scotland-9781788515276/

Seyfang, G., Hielscher, S., Hargreaves, T., Martiskainen, M., \& Smith, A. (2014). A grassroots sustainable energy niche? Reflections on community energy in the UK. Environmental Innovation and Societal Transitions, 13(1), 21-44. https://doi.org/10.1016/j.eist.2014.04.004

Simcock, N., Willis, R., \& Capener, P. (2016). Cultures of Community Energy. International Case Studies, Lancaster Environment

Centre, Lancaster University. Retrieved from 
https://www.thebritishacademy.ac.uk/documents/137/CoCE_International_Case_Studies_online.pdf

Smith, A. (2016). Alternative technology niches and sustainable development: 12 years on. Innovation: Management, Policy \& Practice, 18, 485-488. https://doi.org/10.1080/14479338.2016.1241153

Smith, A., Hargreaves, T., Hielscher, S., Martiskainen, M., \& Seyfang, G. (2016). Making the most of community energies: Three perspectives on grassroots innovation. Environment and Planning A, 48, 407-432. https://doi.org/10.1177/0308518X15597908

Strachan, P. A., Cowell, R., Ellis, G., Sherry-Brennan, F., \& Toke, D. (2015). Promoting community renewable energy in a corporate energy world. Sustainable Development, 23(2), 96-109. https://doi.org/10.1002/sd.1576

Sunny, S. A., \& Shu, C. (2017). Investments, incentives, and innovation: Geographical clustering dynamics as drivers of sustainable entrepreneurship. Small Business Economics, 52, 905-927. https://doi.org/10.1007/s11187-017-9941-z

Thompson, N. A., Herrmann, A. M., \& Hekkert, M. P. (2015). How sustainable entrepreneurs engage in institutional change: Insights from biomass torrefaction in the Netherlands. Journal of Cleaner Production, 106, 608-618. https://doi.org/10.1016/j.jclepro.2014.08.011

Urbaniec, M. (2018). Sustainable entrepreneurship: Innovation-related activities in European enterprises. Polish Journal of Environmental Studies, 27, 1773-1779. https://doi.org/10.15244/pjoes/78155

Van Horne, C., \& Dutot, V. (2017). Challenges in technology transfer: An actor perspective in a quadruple helix environment. The Journal of Technology Transfer, 42, 285-301. https://doi.org/10.1007/s10961-016-9503-6

Vuorio, A. M., Puumalainen, K., \& Fellnhofer, K. (2018). Drivers of entrepreneurial intentions in sustainable entrepreneurship. International Journal of Entrepreneurial Behavior \& Research, 24, 359-381. https://doi.org/10.1108/JJEBR-03-2016-0097

Willis, R., Simcock, N. (2019) Consumer (Co-)Ownership of Renewables in England and Wales (UK). In J. Lowitzsch (Ed.), Energy transition (pp. 369-394). https://doi.org/10.1007/978-3-319-93518-8_17

\section{Copyrights}

Copyright for this article is retained by the author(s), with first publication rights granted to the journal.

This is an open-access article distributed under the terms and conditions of the Creative Commons Attribution license (http://creativecommons.org/licenses/by/4.0/). 